\title{
ASAS KEADILAN DALAM PERATURAN PRESIDEN NOMOR 20 TAHUN 2018 TENTANG PENGGUNAAN TENAGA KERJA ASING
}

\author{
Lis Setiyowati \\ LLDIKTI Wilayah VI Jawa Tengah \\ Korespondensi: olisiasw@gmail.com \\ Budi Ispriyarso \\ Fakultas Hukum Universitas Diponegoro
}

\begin{abstract}
Abstrak
Peraturan Presiden Nomor 20 Tahun 2018 tentang Penggunaan Tenaga Kerja Asing menimbulkan keresahan di masyarakat. Peraturan tersebut memperlihatkan keberpihakan, kemudahan yang diberikan Pemerintah kepada Tenaga Kerja Asing (TKA). Keberpihakan Pemerintah terhadap TKA terlihat pada Pasal 9, ijin Menggunakan TKA tidak diperlukan lagi, cukup dengan Rencana Penggunaan TKA. Pasal 10, TKA yang bekerja di bidang yang dibutuhkan Pemerintah juga tidak diperlukan ijin dulu. Hal tersebut tidak adil jika dilihat dengan prinsip keadilan yang diungkapkan Rawls dan Hamid A. Tamimi, bahwa keadilan lebih kepada jika tujuan negara dapat terwujud, berkaitan dengan mewujudkan kesejahteraan umum. Kemudahan terhadap TKA kontradiktif dengan tingginya angka pengangguran di Indonesia. Selain itu, bertentangan dengan Undang-Undang Nomor 13 Tahun 2003 dan tidak menganut asas materi muatan Peraturan Perundang-undangan.
\end{abstract}

Kata Kunci: Asas Keadilan; Tenaga Kerja Asing; Keberpihakan.

\begin{abstract}
Abstrak
Presidential Regulation No. 20 of 2018 concerning the Use of Foreign Workers has caused unrest in the public. The regulation shows a partisanship and a convenience which are provided by the Government to Foreign Workers. The government's partisanship to Foreign Workers is indicated by the existence of Article 9 of the Regulation which states that the Permits to Use Foreign Workers are no longer needed. Instead of the Permits, the Plan for the Use of Foreign Workers is being required. In addition, Article 10 of the Regulation also states that the Permits is not needed for Foreign workers who work in certain fields required by the Government. Using the principle of justice by Rawls and Hamid A. Tamimi to justify the Articles, it is concluded that those Articles are unfair since the justice shall be created to achieve the State's goal which is related to increase public welfare. The convenience provided for foreign workers is contradictory to the high unemployment rate in Indonesia. Moreover, it contradicts the 1945 Constitution of the Republic of Indonesia, Law Number 13 Year 2003 and it does not adhere to the material principles of the contents of the Laws and Regulations.
\end{abstract}

Keywords: Principle of Justice; Foreign Workers; Partisanship. 


\section{PENDAHULUAN}

Salah satu tujuan negara yang tercantum dalam Undang-Undang Dasar Negara Republik Indonesia (selanjutnya disebut UUD NRI) Tahun 1945 yaitu memajukan kesejahteraan umum. Menurut Andrew Heywood, paham kesejahteraan secara tradisional menyatakan bahwa kesejahteraan rakyat adalah tanggung jawab masyarakat dan tanggung jawab tersebut dipenuhi oleh pemerintah. ${ }^{1}$ Realisasi dari hal tersebut ada dalam bentuk negara atau pemerintah yang disebut dengan negara kesejahteraan (welfare state). ${ }^{2}$ Indonesia sebagai penganut welfare state, menuangkan konsep tersebut di dalam peraturan perundang-undangan yang dibuat. Salah satu contoh, dalam Pasal 27 ayat (2) UUD NRI Tahun 1945, di dalamnya menyatakan bahwa "tiap-tiap warga negara berhak atas pekerjaan dan penghidupan yang layak". Berarti Negara berkewajiban menjamin warga negara untuk mendapatkan penghidupan yang layak dan dapat terpenuhi untuk mencari dan mendapatkan pekerjaan tanpa dihalangi.

Di era globalisasi sebagai era dimana kemajuan ilmu pengetahuan, teknologi dan alat transportasi yang mendorong kehidupan manusia menjadi tak terbatas secara geografis ataupun budaya, gerak manusia menjadi seolah tidak terbatas. Demikian juga dalam segi ketenagakerjaan. Banyaknya TKA yang masuk ke Indonesia, membuat resah masyarakat. Indonesia sebagai negara berkembang, yang berpenduduk sekitar 260 juta jiwa memiliki jumlah tenaga kerja antar $23 \%$ sampai $70 \%$ dari jumlah penduduk di setiap provinsi. ${ }^{3}$ Jumlah yang sangat besar tersebut, menjadi alasan logis Pemerintah untuk mengatur tentang ketenagakerjaan, sejalan dengan fungsi hukum sebagai pengatur kehidupan bersama manusia.

Berkaitan dengan TKA yang masuk ke Indonesia, Pemerintah mengeluarkan Peraturan Presiden Nomor 20 Tahun 2018 yang mengatur tentang Penggunaan TKA (selanjutnya Perpres No. 20 Tahun 2018). Melalui Perpres ini pemerintah terfokus pada peningkatan investasi di Indonesia dengan memberikan kemudahan proses, kemudahan birokrasi khususnya untuk TKA. Tetapi kemudian Perpres ini menimbulkan polemik dan gejolak di masyarakat khususnya dari tenaga kerja di Indonesia. Mereka menganggap Perpres ini melegitimasi masuknya TKA bekerja di Indonesia. Mereka menganggap serbuan dari TKA tersebut mengancam lapangan kerja yang seharusnya bisa didapatkan oleh Pekerja Indonesia. Apalagi dengan berita yang gencar mengenai serbuan TKA dari China.

Menurut data Kementerian Ketenagakerjaan per November 2016, jumlah TKA secara resmi di Indonesia adalah 74.183 orang. Tenaga kerja asal China sebanyak $28,7 \%$ dari total jumah TKA yang ada di Indonesia, atau sejumlah 21.271 orang. Sehingga negara yang paling tinggi mengirimkan

Andrew Heywood, Politico/Theory (Palgrave Macmillan 2004) dalam Bagir Manan dan Susi Dwi Harijanti, 'Saat Rakyat Bicara: Demokrasi dan Kesejahteraan' (2014) 1 Jurnal Ilmu Hukum 1, 2. Bagir Manan dan Susi Dwi Harijanti, 'Saat Rakyat Bicara: Demokrasi dan Kesejahteraan' (2014) 1 Jurnal Ilmu Hukum 1, 2.

Badan Pusat Statistik, 'Persentase Tenaga Kerja Formal menurut Provinsi Tahun 2015-2018' (2018) <https://www.bps.go.id/dynamictable/2018/05/16\%2000:00:00/1311/persentase-tena ga-kerja-formal-menurut-provinsi-2015---2018.html> diakses 1 September 2018. 
tenaga kerjanya ke Indonesia adalah China. 4

Peningkatan jumlah tenaga kerja asal China diikuti dengan naiknya jumlah kasus TKA ilegal yang berasal dari China. Hal itu diperkuat dengan kenyataan bahwa Kementerian Ketenagakerjaan telah mendeportasi warga negara asing sebanyak 7.877 orang dan merekomendasikan tindakan deportasi terhadap 794 TKA yang tidak memiliki Ijin Memperkerjakan Tenaga Asing (IMTA) dari berbagai negara. Diantaranya adalah 1.837 TKA ilegal berasal dari China. Terdiri dari 239 kasus pidana hukum dan tindakan administratif keimigrasian. Sementara itu, pada tahun 2015 terdapat 225 kasus dan tahun 2014 sebanyak 54 kasus TKA ilegal asal China. ${ }^{5}$

Dengan kondisi demikian, hadirnya Perpres No. 20 Tahun 2018, seolah menambah keresahan pada masyarakat. Peraturan tersebut memberikan gambaran bahwa pemerintah dengan sengaja mempermudah masuknya TKA ke Indonesia. Hal itu mengusik rasa keadilan di masyarakat. Dalam kondisi sulitnya mencari pekerjaan, dan pada kenyataannya banyak tenaga kerja dengan pendidikan Sekolah Menengah Kejuruan (SMK) yang tidak terserap dalam kesempatan kerja, tetapi di sisi lain, pemerintah mempermudah TKA yang akan bekerja di Indonesia dan dianggap sah dengan kemudahan itu.

Berkaitan dengan hal tersebut, penulis merumuskan masalah penelitian yaitu: apakah Perpres tersebut menerapkan asas keadilan, dan apakah peraturan tersebut bertentangan dengan aturan perundangan diatasnya. Tulisan ini menggunakan metode pendekatan yuridis normatif yaitu suatu penelitian hukum yang dilakukan dengan cara meneliti data sekunder berupa bahan hukum primer yaitu peraturan perundang-undangan yang berkaitan dengan tenaga kerja serta bahan hukum sekunder. Bahan hukum sekunder adalah bahan hukum yang memberikan penjelasan mengenai bahan hukum primer, hasil-hasil penelitian, karya ilmiah, hasil karya dari ahli hukum meliputi buku, teks, artikel dalam berbagai majalah ilmiah atau jurnal hasil penelitian di bidang hukum, makalah yang disampaikan dalam berbagai bentuk pertemuan seperti dalam diskusi, seminar maupun lokakarya, dan sebagainya.

Pendekatan yuridis karena hukum dilihat sebagai norma atau das sollen, karena dalam membahas permasalahan penelitian ini menggunakan bahan-bahan hukum primer maupun sekunder. Penelitian normatif, karena pokok kajian adalah hukum yang dikonsepkan sebagai norma atau kaidah yang berlaku dalam masyarakat dan menjadi acuan perilaku setiap orang. ${ }^{6}$ Spesifikasi penelitian yang digunakan dalam penelitian adalah deskriptif analitis. Deskriptif yaitu bersifat memaparkan dan bertujuan memperoleh gambaran (deskripsi) lengkap dengan keadaan hukum yang berlaku di tempat tertentu dan pada saat tertentu, atau mengenai gejala yuridis yang ada, atau peristiwa hukum tertentu yang terjadi dalam masyarakat. Adapun analitis maksudnya dikaitkan dengan teoriteori hukum yang ada dan atau pera-

\footnotetext{
4 Suciliani Octavia dan Muhammad Badaruddin, 'Pengaruh Investasi China Terhadap Penanganan Ketenagakerjaan Asing di Indonesia’ (2017) 2 Jurnal Populis 439, 444.

Suciliani, Op.Cit., 7.

Abdulkadir Muhammad, Hukum dan Penelitian Hukum (Citra Aditya Bakti 2004) 52.
} 
turan perundang-undangan yang berkaitan dengan objek yang diteliti. ${ }^{7}$

\section{PEMBAHASAN}

\section{Asas Keadilan}

Menurut Socrates, adil adalah jika kewajiban sebagai warga negara yaitu menaati hukum negara dapat ditunaikan. ${ }^{8}$ Menurut Plato ada dua prinsip tentang keadilan, yaitu adil jika kepada yang sama diberikan yang sama, dan kepada yang tidak sama diberikan yang tidak sama. ${ }^{9}$ Sedangkan Stammler mengungkapan bahwa keadilan yaitu usaha atau tindakan mengarahkan hukum positif sebagai usaha dengan sanksi pemaksa menuju sesuatu yang adil (Zwangversuch zum Richtigen). Keadilan ialah usaha atau tindakan mengarahkan hukum positif kepada cita hukum. ${ }^{10}$

Berdasarkan fungsinya, hukum untuk memelihara kepentingan umum dalam masyarakat, menjaga hak manusia, dan mewujudkan keadilan di "hidup bersama" masyarakat. Tujuantujuan tersebut mengisi sebuah konsep dasar dimana manusia harus hidup dalam suatu masyarakat. Masyarakat diatur oleh Pemerintah berdasarkan hukum. Oleh karena itu, Stamler memfokuskan bahwa keadilan sebagai tujuan hukum. Menurut Radbruch pula, arah yang berbedabeda dalam keadilan sebagai tujuan umum, untuk mencapai keadilan sebagai tujuan dari hukum. ${ }^{11}$
Tiga prinsip keadilan menurut Ulpian, yaitu Honeste vivere, alterum non laedere, sum quique tribuere (hidup secara terhormat, tidak mengganggu orang lain, dan memberi kepada tiap orang bagiannya). ${ }^{12}$ Prinsip-prinsip tersebut sebagai sebuah tolok ukur tentang apa yang baik, benar dan tepat dalam hidup. Oleh karena itu, keadilan mengikat semua orang penguasa maupun masyarakat. Prinsip yang diajukan Ulpian tersebut didukung oleh Agustinus. Agustinus menambahkan dua prinsip lagi yakni, deligere (dihargai dan dicintai) dan delicto proximi (mengasihi sesama). ${ }^{13}$

Terdapat dua macam keadilan berbasis kesamaan yang diungkapkan oleh Aristoteles, yakni keadilan komutatif dan distributif. Keadilan komutatif yaitu keadilan yang memberikan pada setiap orang sama banyaknya dengan tanpa mengingat jasa-jasa perseorangan. ${ }^{14}$ Sedangkan Keadilan distributif didefinisikan sebagai keadilan yang memberikan kepada setiap orang jatah menurut jasanya (pembagian menurut haknya masingmasing). Keadilan ini tidak menuntut agar tiap-tiap orang mendapat bagian yang sama banyaknya; tetapi intinya pada kesebandingan bukan persamaan. ${ }^{15}$

John Rawls memandang suatu keadilan adalah fairness. Salah satu bentuk keadilan fairness adalah memandang berbagai pihak dalam

Ronny Hanitijo Soemitro, Metodologi Penelitian Hukum dan Jurimetri (Ghalia Indonesia 1994) 52.

Bernard L. Tanya, Politik Hukum Agenda Kepentingan Bersama (Genta Publishing 2011) 23.

Ibid.

10 Maria Farida Indrati Soprapto, Imu Perundang-Undangan I (Jenis, Fungsi, Materi Muatan) (Kanisius 2007) 263.

11 Inge Dwisvimiar, 'Keadilan dalam Perspektif Filsafat Hukum’ (2011) 11 Jurnal Dinamika Hukum, 524, 526.

Bernard, Op. Cit., 24

Ibid.

Sudikno Mertokusumo, Penemuan Hukum Sebuah Pengantar (Cahaya Atma Pustaka 2014) 79.

Ibid., 78. 
situasi awal dalam posisi rasional dan sama-sama netral. Konsep tersebut tertuang dalam bukunya yang berjudul A Theory Of Justice. Ada dua prinsip keadilan yang diusung oleh Rawls yakni :

1. Setiap orang mempunyai hak yang sama atas kebebasan dasar yang paling luas, seluas kebebasan yang sama bagi semua orang.

2. Ketimpangan sosial ekonomi mesti diatur sedemikian rupa sehingga

a) Dapat diharapkan memberi keuntungan

b) Semua posisi dan jabatan terbuka bagi semua orang. ${ }^{16}$

Rawls, berpendapat bahwa syarat keadilan dapat ditegakkan jika negara melaksanakan asas keadilan, dalam wujud setiap orang memiliki hak yang sama untuk mendapatkan kebebasan dasar (basic liberties); perbedaan sosial dan ekonomi diatur sedemikian rupa sehingga memberi manfaat yang besar bagi mereka yang berkedudukan paling tidak beruntung, dan berkaitan dengan jabatan serta kedudukan yang terbuka bagi semua orang berdasarkan persamaan kesempatan yang layak. ${ }^{17}$ Teori Rawls berdasar pada dua prinsip yaitu melihat tentang Equal Right dan Economic Equality. ${ }^{18}$ Lebih lanjut menurut A. Hamid S. Attamimi hukum yang adil (richtigen recht) ialah hukum positif yang memiliki sifat yang diarahkan oleh cita hukum untuk mencapai tujuan masyarakat. ${ }^{19}$

Dari beberapa teori yang diungkapkan oleh beberapa tokoh di atas, ada beberapa garis besar yang dapat ditarik berhubungan dengan
Keadilan, yaitu seagai usaha atau tindakan mengarahkan hukum positif kepada cita hukum. Keadilan sebagai salah satu tujuan dari hukum itu sendiri. Prinsip-prinsip keadilan menjadi tolok ukur apa yang baik dan benar dalam masyarakat, dan prinsip tersebut mengikat baik kepada masyarakat maupun penguasa.

Selain prinsip hidup secara terhormat, tidak mengganggu orang lain, dan memberi kepada tiap orang bagiannya, prinsip dihargai dan dicintai, serta mengasihi sesama juga melengkapi prinsip keadilan. Dalam konteks negara, penguasa akan baik dan benar jika berdasarkan prinsip tersebut, dimana pemerintah harus mencintai masyarakat dengan salah satunya tidak membuat kebijakan yang menyakiti atau membuat masyarakat lebih menderita.

Prinsip keadilan selanjutnya, ketika setiap orang mempunyai hak yang sama atas kebebasan dasar yang paling luas, seluas kebebasan yang sama bagi semua orang. Ketimpangan sosial harus teratasi untuk mewujudkan sebuah keadilan sehingga manfaat paling besar dapat dirasakan oleh masyarakat dengan mendapatkan kesempatan yang sama. Pada akhirnya hukum untuk mencapai tujuantujuan masyarakat.

\section{Penerapan Asas Keadilan dalam Peraturan Presiden No. 20 Tahun 2018}

Produk hukum yang adil tentunya dihasilkan dari pembentukan sebuah

\footnotetext{
16 John Rawls, 'A Theory of Justice', Terjemahan Uzair Fauzan dan Heru Prasetyo (Pustaka Pelajar 2011) dalam Nabitatus Sa'adah, 'Kebijakan Pengampunan Pajak (Tax Amnesty) Berdasarkan Keadilan yang Mendukung Iklim Investasi Indonesia' (2017) 46 MasalahMasalah Hukum 185. Inge, Op. Cit., 528.

Ibid.

Maria, Op. Cit.
} 
produk hukum yang menerapkan asas keadilan. Berbicara tentang pembentukan dan hasil produk hukum yang adil, akan terkait dengan definisi atau pengertian tentang keadilan itu sendiri.

Keadilan sosial bagi seluruh rakyat Indonesia sebagai sila ke lima Pancasila, menjadi tujuan dari empat sila yang lain. Di dalamnya terkandung sila-sila yang lain. ${ }^{20}$ Kemudian, di dalam Pembukaan UUD NRI Tahun 1945 disebutkan bahwa "......mengantarkan rakyat Indonesia ke depan pintu gerbang kemerdekaan negara Indonesia, yang merdeka, bersatu, berdaulat, adil, dan makmur". Katakata "adil dan makmur" tertulis secara eksplisit, sehingga secara jelas kehidupan bernegara bangsa Indonesia haruslah menjunjung tinggi keadilan. ${ }^{21}$

Salah satu tujuan negara yang tercantum dalam Pembukaan UUD NRI Tahun 1945 adalah memajukan kesejahteraan umum. Kata-kata "adil" disebutkan dengan tegas di dalam Pancasila maupun Pembukaan UUD NRI Tahun 1945. Kata-kata adil dan makmur, tidak dapat dipisahkan begitu saja, yang mencerminkan bahwa bangsa Indonesia berkeinginan untuk menerapkan keadilan dalam segala hal dengan tidak lupa memakmurkan rakyat Indonesia.

Makmur dekat artinya dengan sejahtera. ${ }^{22}$ Pengertian makmur yaitu tercapainya pemenuhan kebutuhan hidup. Pembangunan nasional yang terpadu dan menyeluruh dengan berdasarkan prinsip adil dan makmur melahirkan kesejahteraan umum. ${ }^{23}$ Sila ke lima Pancasila dapat dimaknai bahwa keadilan yang diwujudkan, tidak hanya untuk seseorang atau sebagian orang tetapi bagi dan dirasakan oleh seluruh rakyat Indonesia.

Keadilan sosial jika diartikan sebagai kebahagiaan sosial, maka untuk mencapai kebahagiaan sosial tersebut, kebutuhan individu sosial harus terpenuhi. Tata aturan yang adil menjamin terpenuhinya kebutuhan individu sosial. ${ }^{24}$ Oleh karena itu, dalam pembuatan suatu produk hukum haruslah diterapkan asas keadilan. Hal itu tercantum dalam Pasal 6 UU No. 12 Tahun 2011 tentang Pembentukan Peraturan Perundangundangan yang menyebutkan bahwa salah satu asas materi muatan peraturan perundang-undangan yakni asas keadilan. Dalam Penjelasan UU No. 12 Tahun Tahun 2011 yang dimaksud dengan "asas keadilan" adalah bahwa setiap materi muatan peraturan perundang-undangan harus mencerminkan keadilan secara proporsional bagi setiap warga negara.

Prinsip keadilan mengikat tidak hanya masyarakat tetapi juga penguasa, seperti yang diungkapkan oleh Ulpian. Penguasa jika kita kaitkan dengan Pemerintah, dalam membuat sebuah produk hukum tidak boleh mengabaikan prinsip keadilan. Peraturan yang dibuat harus dapat

\footnotetext{
Notonagoro, Pancasila Secara Ilmiah Populer (Bumi Aksara 1995) 156.

Ibid., 157.

Hendarto Supatra, 'Kajian Semantik kata 'Damai Sejahtera' dalam Bahasa Indonesia' (2017) 12 Jurnal Nusa 154, 159.

23 Sudjana, 'Hakikat Adil Dan Makmur Sebagai Landasan Hidup dalam Mewujudkan Ketahanan Untuk Mencapai Masyarakat Sejahtera Melalui Pembangunan Nasional Berdasarkan Pancasila' (2018) 24 Jurnal Ketahanan Nasional 135, 136.

24 Jimly Asshiddiqie dan M. Ali Safa'at, Teori Hans Kelsen Tentang Hukum (Konstitusi Pers 2012) 17.
} 
mengakomodasi berbagai kepentingan untuk kesejahteraan masyarakat luas.

Kesempatan kerja bagi masyarakat Indonesia berkaitan dengan kepentingan masyarakat luas, penghidupan yang layak, yang akhir-nya bermuara pada kesejahteraan. Harapan untuk mendapatkan kesejahteraan melalui pekerjaan yang layak dan kesempatan yang sama dalam memperolehnya, tidak dapat diabaikan begitu saja. Seperti yang tercantum dalam Pasal 5 UU No. 13 Tahun 2003 tentang Ketenagakerjaan yang menyebutkan "setiap tenaga kerja memiliki kesempatan yang sama tanpa diskriminasi untuk memperoleh pekerjaan". Seperti yang dikatakan oleh Ulpian, bahwa keadilan mengikat penguasa dan masyarakat, sehingga Perpres No. 20 Tahun 2018 dirasakan mengusik prinsip keadilan alterum non laedere, sum quique tribuere. Masyarakat merasa ter-ganggu, dibedakan dengan kemuda-han yang diberikan justru kepada TKA dengan mengatasnamakan peningka-tan investasi.

Perpres No. 20 Tahun 2018 ditetapkan dengan tujuan untuk mendukung perekonomian nasional dan perluasan kesempatan kerja melalui peningkatan investasi. Sejalan dengan makin derasnya arus investasi, Indonesia juga dinilai makin berpotensi menerima masuknya TKA dengan kualifikasi tertentu yang dibutuhkan dalam investasi. Hal tersebut adalah untuk bisa memastikan kepentingan nasional dengan meningkatkan daya tarik investasi maupun kepentingan terserapnya tenaga kerja dalam negeri. Atas alasan tersebut, perlu regulasi untuk menata masuknya TKA. Selain itu, guna menggerakkan ekonomi di luar APBN agar bisa tumbuh secara berkualitas yang salah satu kuncinya terletak di investasi. ${ }^{25}$

Lembaga Ilmu Pengetahuan Indonesia (LIPI) mencatat terjadi peningkatan investasi China ke Indonesia. Pada 2016, China telah duduk di posisi ke-3 sebagai investor terbesar dengan nilai investasi USD 2,665 juta atau 9 persen dari total investasi di Indonesia. Naik dari 2015 sebesar USD 628 juta atau 2 persen dari total investasi asing di Indonesia. Peningkatan investasi oleh China tersebut berdampak dengan meningkatnya jumlah tenaga kerja asal Cina ke Indonesia. China meningkatkan investasi diiringi pengiriman tenaga kerja mereka ke proyek investasi mereka. ${ }^{26}$

Faktor-faktor yang menyebabkan maraknya TKA khususnya dari Tiongkok, antara lain :27

1. Faktor keterbukaan investasi di Indonesia. Sebagaimana kita ketahui saat ini Indonesia sedang giat-giatnya membangun dan ada program pemerintah dalam rangka percepatan pembangunan sehingga untuk mendatangkan investor dalam satu paket dengan tenaga kerjanya (mulai dari top manager sampai tenaga buruhnya).

25 Ari Nursanti, 'Perpres Tenaga Asing untuk Tarik Investasi' (2018) <https://www.pikiranrakyat.com/nasional/2018/04/12/perpres-tenaga-asing-untuk-tarik-investasi-422715> diakses 14 September 2018.

26 Wilfridus Setu Embu, Terbongkar, 'Alasan Indonesia dibanjiri Tenaga Kerja Asing terutama Asal China' (2018) <https://www.merdeka.com/uang/terbongkar-alasan-indonesia-dibanjiri-tenagakerja-asing-terutama-asal-china.html> diakses 14 September 2018.

27 Ahmad Jazuli, 'Eksistensi Tenaga Kerja Asing Di Indonesia Dalam Perspektif Hukum Keimigrasian' (2018) 12 Jurnal Ilmiah Kebijakan Hukum 89, 93. 
2. Faktor kebijakan bebas visa. Dengan dibukanya pintu masuk orang asing tanpa visa (169 negara), maka banyak dari warna negara Tiongkok yang datang ke Indonesia, dan berdampak pada peningkatan pelanggaran keimigrasian.

3. Pemberlakuan Masyarakat Ekonomi ASEAN (MEA). Hal ini menyebabkan terbukanya sekat antar negara (border less) dan meningkatnya kedatangan TKA.

Data dari Badan Pusat Statistik (BPS), angka pengangguran di Indonesia pada tahun 2018 adalah 6,87 juta jiwa ${ }^{28}$. BPS merilis tingkat pengangguran terbuka (TPT) di Indonesia di Februari 2018 sampai $5,13 \%$, atau turun dari periode sama tahun sebelumnya yaitu $5,33 \%$. Berdasarkan persentase tersebut, jumlah pengangguran di Indonesia yang sebelumnya yang mencapai 7,01 juta orang saat ini turun pada angka 6,87 juta orang. TPT terbesar berada pada level SMK yang mencapai $8,92 \%$. Kemudian, setelah itu pada level Diploma I/II/III sebesar 7,92\%. Itu artinya banyak di tingkat pendidikan ini yang tidak terserap. Perbandingan antara kota dan desa, tingkat pengangguran di kota jauh lebih tinggi dibanding di desa. TPT di wilayah perkotaan yaitu $6,34 \%$, sementara TPT di wilayah pedesaan sebesar 3,72\%.29 Tetapi bagaimana-pun, jumlah pengangguran masih cukup besar dan terbesar pada level SMK.

Kondisi semacam itu, menjadi kontradiktif dengan sikap pemerintah yang mengeluarkan Perpres No. 20 Tahun 2018 tentang Penggunaan TKA.
Dalam Pasal 9 Perpres ini, IMTA tidak dibutuhkan lagi, bertolak belakang dengan yang disyaratkan dalam Perpres Nomor 72 Tahun 2014 tentang Penggunaan TKA serta Pelaksanaan Pendidikan dan Pelatihan Tenaga Kerja Pendamping. Dalam Peraturan Presiden No. 20 tahun 2018 pengusaha yang akan mempekerjakan TKA cukup mengajukan Rencana Penggunaan Tenaga Kerja Asing (RPTKA) tanpa harus mengajukan IMTA.

Hal tersebut juga bertentangan dengan Pasal 42 ayat (1) UU No. 13 Tahun 2003 tentang Ketenagakerjaan yang berbunyi "Setiap pemberi kerja yang mempekerjakan TKA wajib memiliki izin tertulis dari Menteri atau pejabat yang ditunjuk". Kemudian dalam Pasal 43 ayat (1) bahwa "Pemberi kerja yang menggunakan TKA harus memiliki rencana penggunaan TKA yang disahkan oleh Menteri atau pejabat yang ditunjuk". Dalam Penjelasan Pasal 43, RPTKA merupakan persyaratan untuk mendapat izin kerja. Berdasarkan penjelasan Pasal 43 ini, RPTKA dan Izin Penggunaan TKA menjadi hal yang berbeda, dan RPTKA menjadi syarat untuk mendapat izin tersebut.

Pasal 10 Ayat (1) huruf a Perpres No. 20 Tahun 2018 mengatur pemegang saham yang menjabat sebagai direksi atau komisaris tidak diwajibkan memiliki RPTKA. Sementara dalam UU No. 13 Tahun 2003 mewajibkan TKA termasuk komisaris dan direksi harus memiliki izin, dan diwajibkan memiliki RPTKA. Hal yang tidak diwajibkan untuk komisaris dan direksi hanyalah menunjuk tenaga

\footnotetext{
28 Lily Rusna Fajriah, 'BPS: Jumlah Pengangguran di. Indonesia Capai 687 Juta' (2018) <https ://ekbis.sindonews.com/read/1303706/33/bps-jumlah-pengangguran-di-indonesia-capai687-juta-1525681109> diakses 18 September 2018. 
kerja Indonesia sebagai pendamping dan pelatihan pendidikan.

Pasal 10 Ayat (1) huruf c Perpres ini menyebutkan, pemberi kerja TKA tidak wajib memiliki RPTKA untuk mempekerjakan TKA pada jenis pekerjaan yang dibutuhkan pemerintah. Pasal ini menunjukkan ada pengecualian bagi pemberi kerja TKA untuk tidak mengurus RPTKA. Dalam frase yang menyatakan, 'Pekerjaan yang dibutuhkan Pemerintah', berarti membuka ruang bagi TKA yang bekerja di luar instansi pemerintah dengan tidak diwajibkan memiliki RPTKA. Padahal, dalam Pasal 43 Ayat (3) UU No. 13 tahun 2003, yang dikecualikan hanya bagi instansi pemerintah, badan-badan internasional dan perwakilan negara asing. 30 Peraturan menteri tentang jenis pekerjaan yang dibutuhkan oleh pemerintah masih dalam tahap rencana untuk disusun. ${ }^{31}$

Jumlah pengangguran Indonesia yang berada di angka 6,7 juta orang, terancam dengan masuknya TKA di Indonesia. Berdasarkan data Kementerian Ketenagakerjaan per Maret 2018, ada sekitar 126.000 TKA yang ada di Indonesia. Pada November 2016 jumlah TKA 74.183 dengan jumlah paling banyak TKA berasal dari Cina yaitu 21.271 orang. Pada akhir 2017, jumlah TKA mencapai hampir 85.974 orang dan 24.800 di antaranya berasal dari Cina. ${ }^{32}$ Kecenderungan kenaikan jumlah tersebut, seharusnya membuat Pemerintah lebih waspada dengan memperketat Peraturan bagi
TKA, mengingat masyarakat yang membutuhkan pekerjaan juga lebih dari 6 juta orang.

Beberapa kemudahan yang diberikan kepada TKA, diasumsikan menjadi sebuah keber-pihakan dan perlakuan istimewa oleh Pemerintah terhadap TKA. Point inti yang meresahkan masyarakat adalah keberpihakan dan keistimewaan tersebut. Jika kita menilik kembali prinsip keadilan yang diusung oleh Rawls yaitu setiap orang mempunyai hak yang sama atas kebebasan dasar yang paling luas, seluas kebebasan yang sama bagi semua orang, maka keistimewaan yang diberikan kepada TKA tersebut menjadi tidak adil.

Lebih jelasnya, kemudahan yang diberikan oleh Pemerintah akan terlihat dalam tabel Ketidaksesuian Pasal dalam Perpres No. 20 Tahun 2018 dengan UU No. 13 Tahun 2003 berikut ini :

30 Dylan Aprialdo Rahman, 'Perpres TKA dianggap terburu-buru dan Melanggar Undang-Undang' (2018) <https://nasional.kompas.com/read/2018/04/28/08473441/perpres-tka-dianggapterbu ru-buru-dan-melanggar-undang-undang> diakses 2 September 2018.

31 Muhammad Hendartyo, Martha Warta, 'Pemerintah Siapkan Aturan Turunan Perpres Tenaga Kerja Asing' (2018) <https://bisnis.tempo.co/read/1080661/pemerintah-siapkan-aturanturunan-perpres-tenaga-kerja-asing/full\&view=ok> diakses 19 September 2018.

32 BBC Indonesia, 'Apa Dibalik Simpang Siur Peraturan Presiden Tentang Tenaga Kerja Asing' (2018) <https://www.bbc.com/indonesia/indonesia-43872117> diakses 2 September 2018. 
Tabel 1. Ketidaksesuian Pasal dalam Perpres Nomor 20 Tahun 2018 dengan UU Nomor 13 Tahun 2003.

\begin{tabular}{|c|c|}
\hline $\begin{array}{l}\text { UU No. } 13 \text { Thn } 2003 \text { tentang } \\
\text { Ketenagakerjaan }\end{array}$ & $\begin{array}{l}\text { Perpres No } 20 \text { Thn } 2018 \text { tentang } \\
\text { Penggunaan Tenaga Kerja Asing }\end{array}$ \\
\hline $\begin{array}{l}\text { Pasal } 42 \text { ayat (1) } \\
\text { Setiap pemberi kerja yang } \\
\text { mempekerjakan tenaga kerja asing } \\
\text { wajib memiliki izin tertu-lis dari Menteri } \\
\text { atau pejabat yang ditunjuk. } \\
\text { Pasal } 43 \text { ayat (1) } \\
\text { Pemberi kerja yang menggunakan } \\
\text { tenaga kerja asing harus memiliki } \\
\text { rencana peng-gunaan tenaga kerja } \\
\text { asing yang disahkan oleh Menteri atau } \\
\text { pejabat yang ditunjuk. }\end{array}$ & $\begin{array}{l}\text { Pasal } 7 \text { ayat (1) } \\
\text { Setiap Pemberi Kerja TKA yang } \\
\text { menggunakan TKA harus memiliki RPTKA } \\
\text { yang disahkan oleh Menteri atau pejabat } \\
\text { yang ditunjuk. }\end{array}$ \\
\hline $\begin{array}{l}\text { Penjelasan Pasal } 43 \text { ayat (1) } \\
\text { Rencana penggunaan tenaga kerja } \\
\text { warga negara asing merupakan } \\
\text { persyaratan untuk mendapatkan izin } \\
\text { kerja (IKTA). }\end{array}$ & $\begin{array}{l}\text { Pasal 9 } \\
\text { Pengesahan RPTKA sebagaimana } \\
\text { dimaksud dalam Pasal } 8 \text { merupakan izin } \\
\text { untuk mem-pekerjakan TKA. }\end{array}$ \\
\hline $\begin{array}{l}\text { Pasal } 42 \text { ayat (3) } \\
\text { Kewajiban memiliki izin sebagaimana } \\
\text { dimaksud dalam ayat (1), tidak berlaku } \\
\text { bagi perwakilan negara asing yang } \\
\text { memper-gunakan tenaga kerja asing } \\
\text { sebagai pegawai diplomatik dan } \\
\text { konsuler }\end{array}$ & $\begin{array}{l}\text { Pasal } 10 \text { ayat (1) } \\
\text { Pemberi Kerja TKA tidak wajib memiliki } \\
\text { RPTKA untuk mempekerjakan TKA yang } \\
\text { merupakan: } \\
\text { a. pemegang saham yang menjabat sebagai } \\
\text { anggota Direksi atau anggota Dewan } \\
\text { Komisaris pada Pemberi Kerja TKA; } \\
\text { b.pegawai diplomatik dan konsuler pada } \\
\text { kantor perwakilan negara asing; atau } \\
\text { c.TKA pada jenis pekerjaan yang } \\
\text { dibutuhkan oleh pemerintah. } \\
\text { Pasal } 10 \text { ayat (2) } \\
\text { Jenis pekerjaan yang dibutuhkan oleh } \\
\text { pemerintah sebagaimana dimaksud pada } \\
\text { ayat (1) huruf c ditetapkan oleh Menteri. }\end{array}$ \\
\hline
\end{tabular}

Menurut Rawls perbedaan sosial dan ekonomi harus diatur sedemikian rupa sehingga memberi manfaat yang besar bagi mereka yang berkedudukan paling tidak beruntung. Jika kita mengasumsikan pengangguran di negara kita sebagai pihak yang "kurang beruntung", dapat dikatakan tidak adil jika justru TKA dipermudah untuk bekerja di Indonesia.

Menurut A. Hamid S. Attamimi hukum yang adil (richtigen recht) ialah hukum positif yang memiliki sifat yang diarahkan oleh cita hukum untuk mencapai tujuan-tujuan masyarakat. Jika kita kaitkan dengan tujuantujuan masyarakat yang kemudian 
kita kembalikan lebih luas lagi menjadi tujuan negara, yakni memajukan kesejahteraan, maka kemudahan dan keberpihakan yang diberikan Pemerintah kepada TKA melalui Perpres Nomor 20 Tahun 2018 tidak dapat disebut sejalan dengan tujuan negara.

Pasal 7 ayat (2) UU No. 12 Tahun 2011 mengatur bahwa "Kekuatan hukum Peraturan Perundangundangan sesuai dengan hierarki sebagaimana dimaksud pada ayat (1)." Dalam Penjelasan Pasal 7 ayat (2), yang dimaksud dengan "hierarki" adalah penjenjangan setiap jenis peraturan perundang-undangan yang didasarkan pada asas bahwa peraturan perundang-undangan yang lebih rendah tidak boleh bertentangan dengan peraturan perundang-undangan yang lebih tinggi. Berdasarkan tabel 1 beberapa pasal dalam Perpres Nomor 20 Tahun 2018 bertentangan dengan beberapa Pasal dalam UU No. 12 Tahun 2011, sedangkan kedudukan UU dalam hierarki peraturan perundang-undangan lebih tinggi daripada Perpres.

Berkaitan dengan hierarki norma hukum, Hans Kelsen mengemukakan teorinya mengenai jenjang norma hukum (Stufenbautheorie) sebagaimana disitir oleh Maria Farida dalam bukunya Ilmu Perundang-undangan dimana ia berpendapat bahwa normanorma hukum itu berjenjang-jenjang dan berlapis-lapis dalam suatu hierarki tata susunan, di mana suatu norma yang lebih rendah berlaku, bersumber, dan berdasar pada norma yang lebih tinggi, norma yang lebih tinggi, berlaku, bersumber dan berdasar pada norma yang lebih tinggi lagi, demikian seterusnya sampai pada suatu norma yang tidak dapat ditelusuri lebih lanjut dan bersifat hipotetis dan fiktif, yaitu Norma Dasar (grundnorm). ${ }^{33}$ Jenjang-jenjang ini memberikan arti bahwa suatu aturan bersumber dari aturan di atasnya sehingga ia tidak boleh bertentangan dengan aturan di atasnya. ${ }^{34}$

Pasal 7 ayat (1) UU No. 12 Tahun 2011 disebutkan bahwa jenis dan hierarki peraturan perundangundangan terdiri atas :

a. Undang-Undang Dasar Negara Republik Indonesia Tahun 1945;

b. Ketetapan Majelis Permusyawaratan Rakyat;

c. Undang-Undang/Peraturan

Pemerintah Pengganti UndangUndang;

d. Peraturan Pemerintah;

e. Peraturan Presiden;

f. Peraturan Daerah Provinsi; dan

g. Peraturan Daerah Kabupaten/ Kota.

Dalam hierarki peraturan perundang-undangan tersebut, Perpres kedudukannya di bawah UndangUndang. Berdasarkan Tabel 1, ada beberapa pasal dalam Perpres yang bertentangan dengan UU No. 13 Tahun 2003. Pasal-Pasal tersebut yakni pasal 7 ayat 1 , Pasal 9, Pasal 10 ayat 1 dan ayat 2 .

Lebih daripada itu, dalam pembentukan sebuah peraturan perundang-undangan tidak boleh mengabaikan asas-asas peraturan perundang-undangan seperti yang tercantum dalam Pasal 6 UU No. 12 Tahun 2011 yakni atas pengayoman; asas kemanusian; asas kebangsaan;

33 Retno Saraswati, 'Problematika Hukum Undang-Undang No. 12 Tahun 2011 tentang Pembentukan Peraturan Perundang-Undangan' (2013) 2 Jurnal Yustisia 97, 98.

34 Sukardi dan E. Prajwalita Widiati, 'Pendelegasian Pengaturan oleh Undang-Undang kepada Peraturan yang Lebih Rendah dan Akibat Hukumnya' (2010) 25 Jurnal Yuridika 103, 105. 
asas kekeluargaan; asas kenusantaraan; asas bhinneka tunggal ika; asas keadilan; asas kesamaan; asas ketertiban dan kepastian hukum; asas keseimbangan, keserasian dan keselarasan.

Adanya Perpres No. 20 Tahun 2018 berpotensi mengancam lapangan pekerjaan dan penghidupan yang layak bagi Tenaga Kerja Indonesia, dan tidak mengedepankan asas pengayoman; asas kemanusiaan; kenusantaraan; keadilan; keseimbangan; keserasian; dan keselarasan. Asas pengayoman berarti bahwa setiap materi muatan peraturan perundang-undangan harus berfungsi memberikan pelindungan untuk menciptakan ketentraman masyarakat. Asas kemanusiaan adalah bahwa setiap materi muatan peraturan perundang-undangan harus mencerminkan perlindungan dan penghormatan hak asasi manusia serta harkat dan martabat setiap warga negara dan penduduk Indonesia secara proporsional.

Makna asas kenusantaraan adalah bahwa setiap materi muatan peraturan perundang-undangan senantiasa memperhatikan kepentingan seluruh wilayah Indonesia dan materi muatan peraturan perundangundangan yang dibuat di daerah merupakan bagian dari sistem hukum nasional yang berdasarkan Pancasila dan UUD NRI Tahun 1945. Sedangkan asas keadilan berarti bahwa setiap materi muatan peraturan perundangundangan harus mencerminkan keadilan secara proporsional bagi setiap warga negara. Kemudian asas keseimbangan, keserasian, dan keselarasan berarti bahwa setiap materi muatan peraturan perundangundangan harus mencerminkan keseimbangan, keserasian, dan keselarasan, antara kepentingan individu, masyarakat dan kepentingan bangsa dan negara.

\section{PENUTUP}

Perpres No. 20 Tahun 2018 tentang Penggunaan TKA diterbitkan dengan pertimbangan untuk meningkatkan perekonomian nasional melalui investasi. Tetapi kemudian dalam Pasal 9 dan 10 perpres tersebut menunjukkan adanya keberpihakan dan kemudahan yang diberikan kepada TKA oleh Pemerintah. Keberpihakan tersebut berupa IMTA tidak diperlukan lagi, tetapi cukup dengan RPTKA. Selain itu TKA yang bekerja di bidang yang dibutuhkan Pemerintah tidak diperlukan ijin lebih dulu. Frase 'bidang yang dibutuhkan Pemerintah' menjadi multitafsir dan memberi celah untuk pekerjaan yang didominasi TKA. Apalagi sampai saat ini, Peraturan Menteri tersebut belum ada, sedangkan TKA yang masuk ke Indonesia terus meningkat. Hal itu menjadi tidak adil dengan mempertimbangkan jumlah pengangguran di Indonesia masih di angka 6,87 juta jiwa. Ketidakadilan tersebut berdasarkan prinsip keadilan yang diungkapkan oleh Rawls yaitu setiap orang mempunyai hak yang sama atas kebebasan dasar yang paling luas, dan perbedaan sosial dan ekonomi diatur sedemikian rupa sehingga memberi manfaat yang besar bagi mereka yang berkedudukan paling tidak beruntung. Kemudian menurut A Tamimi, bahwa keadilan lebih kepada jika tujuan negara dapat terwujud. Selain tidak menerapkan asas asas kebangsaan, keadilan, dan keselarasan sebagai beberapa asas materi muatan peratuturan perundang-undangan dalam UU No. 12 Tahun 2011, bertentangan pula 
dengan UU No. 13 Tahun 2003. Pemerintah seharusnya merevisi Pasal 9 dan 10 dalam Perpres No. 20 Tahun 2018. Pemerintah diharapkan memiliki skema pengendalian yang jelas, baik persyaratan maupun pengawasan dengan mempertegas penegakan hukumnya dalam RPTKA, yang memuat kedudukan dan jabatan TKA dalam struktur organisasi, sehingga meminimalisir unskill foreign worker bekerja di Indonesia. Selain itu perlu mewajibkan TKA untuk menguasai Bahasa Indonesia sebagai upaya pemenuhan asas kebangsaan.

\section{DAFTAR BACAAN}

\section{Buku}

Asshiddiqie, J., dan Safa'at, M. A., Teori Hans Kelsen Tentang Hukum (Konstitusi Pers 2012).

Heywood, A., Politico/Theory (Palgrave Macmillan 2004).

Mertokusumo, S., Penemuan Hukum Sebuah Pengantar, (Cahaya Atma Pustaka 2014).

Muhammad, A., Hukum dan Penelitian Hukum (Citra Aditya Bakti 2004).

Notonagoro, Pancasila Secara Ilmiah Populer (Bumi Aksara 1995).

Rawls, J., 'A Theory of Justice', Terjemahan Uzair Fauzan dan Heru Prasetyo (Pustaka Pelajar 2011).

Soemitro, Ronny H., Metodologi Penelitian Hukum dan Jurimetri, (Ghalia Indonesia 1994).

Soeprapto, Maria Farida I., Ilmu Perundang-undangan I (Jenis, Fungsi, Materi Muatan) (Kanisius 2007).
Tanya, Bernard L., Politik Hukum Agenda Kepentingan Bersama, (Genta Publishing 2011).

\section{Artikel Jurnal}

Dwisvimiar, I., 'Keadilan dalam Perspektif Filsafat Hukum' (2011) 11 Jurnal Dinamika Hukum.

Jazuli, A., 'Eksistensi Tenaga Kerja Asing di Indonesia dalam Perspektif Hukum Keimigrasian' (2018) 12 Jurnal Ilmiah Kebijakan.

Manan, B., dan Harijanti, Susi D., 'Saat Rakyat Bicara: 'Demokrasi dan Kesejahteraan' (2014) 1 Jurnal Ilmu Hukum.

Octavia, S., dan Badaruddin, M., 'Pengaruh Investasi China Terhadap Penanganan Ketenagakerjaan Asing di Indonesia' (2017) 2 Jurnal Populis.

Nabitatus Sa'adah, 'Kebijakan Pengampunan Pajak (Tax Amnesty) Berdasarkan Keadilan yang Mendukung Iklim Investasi Indonesia', (2017) 46 Jurnal MasalahMasalah Hukum.

Saraswati, R., 'Problematika Hukum Undang-Undang No. 12 Tahun 2011 tentang Pembentukan Peraturan Perundang-Undangan', (2013) 2 Jurnal Yustisia.

Sudjana, 'Hakikat Adil dan Makmur Sebagai Landasan Hidup Dalam Mewujudkan Ketahanan Untuk Mencapai Masyarakat Sejahtera Melalui Pembangunan Nasional Berdasarkan Pancasila' (2018) 24 Jurnal Ketahanan Nasional.

Supatra, H., 'Kajian Semantik Kata 'Damai Sejahtera' dalam Bahasa Indonesia' (2017) 12 Jurnal Nusa. 
Sukardi dan Widiati, E. Pr., 'Pendelegasian Pengaturan oleh Undang-Undang kepada Peraturan Yang Lebih Rendahdan Akibat Hukumnya' (2010) 25 Jurnal Yuridika.

\section{Internet}

BBC Indonesia, 'Apa di balik simpang siur Peraturan Presiden tentang tenaga kerja asing?' (2018) <https://www.bbc.com/indonesia /indonesia-43872117> diakses 2 September 2018.

Badan Pusat Statistik, 'Persentase Tenaga Kerja Formal menurut Provinsi Tahun 2015-2018' (2018) <https://www.bps.go.id/dynamict able/2018/05/16\%2000:00:00/ 1

$311 /$ persentase-tenaga-kerja-form al-menurut-provinsi-2015---201

8.html> diakses 1 September 2018.

Embu, Wilfridus S., Terbongkar, Alasan Indonesia Dibanjiri Tenaga Kerja Asing Terutama Asal China' (2018) <https:// www.merdeka.com/uang/terbong kar-alasanindonesiadibanjiri-tena ga-kerja-asing-terutama-asal-chin a.html> diakses $14 \quad$ September 2018.

Fajriah, Lily R., 'BPS : Jumlah Pengangguran di Indonesia Capai 687 Juta' (2018) <httpps:/ / ekbis.sindonews.com/read/13037 06/33/bps-jumlahpenganggurandi-indonesiacapai-687-juta-15256 81109> diakses 18 September 2018.

Hendartyo, M., dan Martha, W., 'Pemerintah Siapkan Aturan Turunan Perpres Tenaga Kerja Asing' (2018) <https:// bisnis.tempo.co/read/1080661/p emerintah-siapkan-aturan-turuna n-perpres-tenaga-kerja-asing/full \&view=ok $>$ diakses 19 September 2019.

Nursanti, Ari, 'Perpres Tenaga Asing untuk Tarik Investasi' (2018) <https://www.pikiran-rakyat.com /nasional/2018/04/12/perpres-t enaga-asing-untuk-tarik-investasi $-422715>$ diakses 14 September 2018.

R. Dylan A., 'Perpres TKA Dianggap Terburu-buru dan Melanggar Undang-Undang' (2018) <https:// nasional.kompas.com/read/2018 /04/28/08473441/perpres-tkadi anggap-terburu-buru-dan-melang gar-undang-undang $>$ diakses 2 September 2018.

\section{Peraturan Perundang-Undangan}

$\begin{array}{crr}\text { Undang-Undang } & \text { Dasar } & \text { Negara } \\ \begin{array}{l}\text { Republik } \\ \text { 1945. }\end{array} & \text { Indonesia } & \text { Tahun } \\ & & \end{array}$

Undang-Undang Nomor 13 Tahun 2003 tentang Ketenagakerjaan.

Undang-Undang Nomor 12 Tahun 2011 tentang Pembentukan Peraturan Perundang-Undangan.

Peraturan Presiden Nomor 72 Tahun 2014 tentang Penggunaan Tenaga Kerja Asing serta Pelaksanaan Pendidikan dan Pelatihan Tenaga Kerja Pendamping.

Peraturan Presiden Nomor 20 Tahun 2018 tentang Penggunaan Tenaga Kerja Asing. 